\title{
Do Roads Enhance Regional Trade? Evidence Based on China's Provincial Data
}

\author{
Imran Ur RAHMAN ${ }^{1}$, Buddhi Prasad SHARMA², Enitilina FETUU ${ }^{3}$, Muhammad YOUSAF $^{4}$
}

Received: September 10, 2020 Revised: November 08, 2020 Accepted: November 16, 2020

\begin{abstract}
We investigate the impact of roads and highways within the provinces on the regional trade of China using the augmented Gravity Model and theory of modeling trade. We take a panel data covering 31 provinces of China over 20 years period (1998-2017) for the estimations. We apply ARMA-OLS model, fixed and random effects, and robust findings by Hausman test. The results imply that road and highway lengths within the provinces have a significantly positive impact on the value of the province-wise exports. The positive impact is due to the fact the increased coverage of roads and highways increase accessibility to resources and mobility of goods and services within the regions. Moreover, employment in the transportation sector, per capita GDP and population of the provinces also illustrate positive and significant influence on regional exports and trade. The impact of China's WTO accession on regional exports has been positive, while the financial crisis has had a negative impact. The year dummies show that, in the years following the financial crisis, China was able to regress from the external shock as trade within the provinces increased. The increase in exports after financial crisis is mainly due to the government policies and support to every province.
\end{abstract}

Keywords: China, Theory of Modeling Trade, Regional Trade, Gravity Model, Roads and Highways

JEL Classification Code: N75, R4, L91, F10

\section{Introduction}

The impact of roads and highways on the socio-economic development roots from the assumption that it fosters growth, enhances mobility and provides easy accessibility to both national and international level markets. Many countries have been able to achieve economic development and growth through developing their physical infrastructure which

${ }^{1}$ First Author and Corresponding Author. Associate Professor, Center for Trans-Himalaya Studies, Leshan Normal University, Sichuan, China [Postal Address: 778 Binhe Road, Shizhong District, Leshan City, Sichuan Province, 614000, China] Email: 2388018157@qq.com

${ }^{2}$ Associate Professor, Center for Trans-Himalaya Studies, Leshan Normal University, Sichuan, China.

Email: buddhi_sharma@outlook.com

${ }^{3}$ Research Scholar, School of Economics, Capital University of Economics and Business, Beijing, China.

Email: nina.fetu@hotmail.com

${ }^{4}$ Research Scholar, School of Economics, University of International

Business and Economics, Beijing, China.

Email: youeco@hotmail.com

(c) Copyright: The Author(s)

This is an Open Access article distributed under the terms of the Creative Commons Attribution Non-Commercial License (https://creativecommons.org/licenses/by-nc/4.0/) which permits unrestricted non-commercial use, distribution, and reproduction in any medium, provided the unrestricted non-commercial use,
original work is properly cited. provided the basic platform to these nations and open new doors of socio-economic development through enhancement of trade and insurance of smooth flow of productions, goods and services within and outside these countries (Calderon \& Serven, 2010).

Most of the developing countries lack good and improved physical infrastructure due to which these countries are facing problems of accessibility, mobility, and transportation of goods and services. Poor physical infrastructure is the main hurdle for the developing countries on their way to achieving development goals and objectives. Poor infrastructure not only affects the livelihoods of the people, but also provides a barrier against socio-economic services including health, education, productivity, efficiency, pollution and other factors (Potluri \& Tejaswi, 2018). The economic activities are halted and the countries face socio-economic downfall with low productions and decreased accessibility to local and international markets. Roads and highways not only provide easy access to services and markets, but also have direct impacts on regional income and output (Calderon \& Serven, 2010; Dorosh et al., 2010, 2012).

Road and highway transport is another important source of transportation of goods and services within cities, states and countries, but also across the borders with other countries 
(Molina, 2008; Molina et al., 2013). Transport of goods and services related to crucial sectors including energy transport like mineral, metals and other natural resources also depend heavily on roads and highways (Yessekina \& Urpekova, 2015). Similarly, the flow of goods and services is ensured due to improved and upgraded roads (Limao, 2001). Regional roads and highways are possibly a good measure of the increase in productions and economic activities within the regions and can lead to better outcomes and socio-economic development of the regions and thus the country (Chandra $\&$ Thompson, 2000). The more the coverage of roads and highways within the regions the higher will be the chances of the region to accelerate its growth through access and utilization of all the available resources.

Although the harbors are continuously providing an easy mean of transportation and shipments of the tradable good, but still the burden is really intense on the coastal provinces due to the competition in the marine transportation service, which is growing with changing international trade environments (Kim \& Kim, 2020). In such a scenario, different governments are focusing on other viable means of transportation in order to bridge the gap between supply and demand in addition to the increased burden on the seaports. Therefore, it is important to understand and study alternative options for the economies.

While it is necessary to develop new approaches for examining different outcomes, it is also important to take the same outcome and use the existing methodologies for different countries and regions. Taking a unique case of China and using panel data for 31 provinces of China for 20 years, this paper will contribute direct evidence in a more appropriate manner to the past studies. China, being a developing nation, has shocked the world with its recent development in all sectors of the economy. The socioeconomic indicators are also showing positive trends (The World Bank, 2015). The export-based economy is showing positive growth for the last three decades with the average growth rate of $7 \%$. This paper will provide further evidence for the existing literature by justifying the assumptions of Theory of Modeling Trade and Gravity Model as there is few empirical evidence on inter-city or inter-province roads and highways relationship with trade flows.

\section{Literature Review}

The importance of regional roads and highways within a country for the enhancement of trade and socio-economic development of a country can never be neglected. Roads and Highways are important sources of trade and economic activity within and across the boundaries of cities, provinces, states, countries, and continents (Ndulu, 2006). On the other hand, poor infrastructure in the form of fewer roads and highways reduces the accessibility to the factors of productions and resources and leads to a reduction in regional and international trade and integration (Francois et al., 2007). Lack of roads and highways halts economic activities and can provide a huge shock to the economic status of the country and can reduce economic growth and development.

Focusing on the importance of roads and highways regarding trade and economic development, many studies have been conducted and the results show the huge significance of the impact of new and improved roads on trade and economic development of a country. Duranton provided some evidence of the impact of roads on regional trade and different type of export goods using the case of the US and Colombia (Duranton, 2015; Duranton et al., 2013). The estimations proved that more roads led towards an increase in the transport of tradable goods and in the case of Colombia the results showed positive relations on soft goods.

Keeping in view the investment in the infrastructure sector, Coşar and Demir (2016) studied the impact of roads on international trade in turkey and found a positive relation between investment on roads and revenues from trade. Further evidence on the impact of improved and quality of roads on the domestic exports and access to international markets was provided by Blyde (2013) showing a significant impact of road quality on local trade and exports. Trade and specialization play a central role in the process of economic growth. Consequently, understanding the forces that promote trade is among the most fundamental problems that economists face. While the literature on trade investigates the effect of trade barriers, the role of transportation costs and infrastructure receives some attention (Coulibaly \& Fontagné, 2006). Venables and Limão (2002) found a strong positive association between an index of infrastructure quality and trade.

However, there are very few papers, which can claim to identify the causal effects of infrastructure on trade. Michaels (2008) examined the effect of access to the interstate highway network on rural counties in the USA. Akpan (2014) also concluded that improvement in road quality leads to increase in intra-regional trade for ECOWAS (Economic Community of West African States was founded in 1975 by 15 African countries, where they signed treaty for trade liberalization) African regions. Moreover, the ancillary benefits of improvement in road quality in terms of increased movement of factors of production will foster further intraregional trade in the medium and long terms. Same results were estimated by Casaburi et al. (2012) and who studied the impacts of improvements in rural road infrastructure on crop prices in rural markets. Fan and Zhang (2004) provided more evidence on the impact of the road infrastructure on rural economic development. Furthermore, Buys et al. (2010) assessed the up-gradation of road networks and their impacts 
Imran Ur RAHMAN, Buddhi Prasad SHARMA, Enitilina FETUU, Muhammad YOUSAF /

Journal of Asian Finance, Economics and Business Vol 7 No 12 (2020) 657-664

on the trade and economy of Sub-Saharan African countries. Sub-Saharan African countries witnessed an increase and expansion in trade due to up-gradation of the transport networks as shown by the results of the study. Using metaanalysis, Celbis et al. (2014) further proved the fact that low levels of infrastructure quality and quantity can create barriers for trade by increasing the transport cost. Using a similar approach, Li et al. (2012) estimated the inter-regional trade barriers and their key components using agricultural traders data in China.

All the past literature and studies have shown the significance of roads and highways in promoting international trade between different countries by improving the flow of tradable goods through easy means of transportation systems. Especially in the case of developing nations, the need for roads and highways is necessary as it enables accessibility to economics inputs and outputs, ensures efficient utilization of knowledge and resources (Services, 2002). Based on these assumptions, this paper will attempt to evaluate and estimate the impact of roads and highways on the regional exports of all the provinces of China with the inclusion of new variables and dummy variables. This paper also takes into account the location of the provinces, there is a huge geographical difference among the province, which can affect the domestic and international trade. Further, the entrance of China into WTO and the impact of the Financial Crisis are also taken as dummy variables, which may explain the changes in the regional trade. The study intends to contribute to the existing literature on the impact of regional road infrastructure on intra-regional trade. In particular, the study will employ the gravity model and theory of modeling trade to examine how roads and highways will improve intra-regional trade in China.

\section{Methodology and Data}

This paper follows the model proposed by Duranton et al. (2013) itself a variant of Anderson and Van Wincoop (2003, 2004) with Armington preferences tailored to assess the issue at hand. The impact of roads on the trade is estimated while considering exports as the main representative of the trade of a province. Secondary data is used for undertaking this research. Most of the past research was based the model panel data, thus, in this case we have also designed the model using panel data taking into consideration the time and group effect of our variables.

For estimation of the model coefficients, secondary data from official sites is collected. Panel data covering all provinces of China, ranging from 1994 to 2013, is taken for estimations. Data on trade, exports, investment, employment, road length, and the population is collected from the relevant offices and departments including the websites of the Bureau of Statistics and Municipal Government databanks. The data on general statistics of China (NBS China, 2020) and LPI ranking of China was collected on World Bank online data site (The World Bank, 2018).

\subsection{Estimation Model}

Based on the methodology and characteristics of the variable, the following model is developed, which is the basic model for the estimation of the coefficients and results:

$$
\begin{aligned}
\ln \exp _{i}= & \beta_{0}+\beta_{1} \ln l r_{i}+\beta_{2} \ln c g d p_{i}+\beta_{3} \ln p o p_{i} \\
& +\beta_{4} \ln e m p_{i}+\beta_{5} w t o-\beta_{6} f r+\mu_{i}
\end{aligned}
$$

The regional exports represented by ' $\exp _{i}$ ' is taken as the dependent variable, which represents the trade of the provinces as per modeling of Akpan who followed the model of Duranton, Morrow and Turner, with addition of new variables for selected African countries, and estimated exports as the proxy variable for trade in their models. Variable $1 r_{i}$ is the main independent variable (regressor), which shows the length of transportation routes (Roads and Highways) within each province of China. Regional population and CGDP of the provinces as represented in the model by pop $_{i}$ and $\operatorname{cgdp}_{i}$ respectively, as these variables provide evidence on the economic conditions of each province and also slight impact on the exports is also considered. The employment in the transportation sector is also considered to have some impact on the provincial trade and export, which is included in the model as "emp.". Apart from main variables that determine the provincial trade and exports, two dummy variables are also added to the model in order to know the impact on the Chinese economy. These two dummy variables are "wto" and "fr" as implied by the model, which explains the effects after China's entry into WTO and Financial Crisis, respectively. As China became a member of WTO in 2001, therefore, the dummy for WTO is assuming the value of " 0 " before 2001 and is taken as "1" after 2001. Similarly, the values of the dummy for the financial crisis are also represented by two values. The value is taken as " 0 " before 2008 and " 1 " after 2008.

\subsection{Summary of Statistics}

The summary of descriptive statistics is shown in Table 1, which provide a brief overview of the variables used for our model. A total of 620 observations for each of the eight variables were estimated including the dependent, independent and dummy variables in the model. The mean value of exports for the provinces was USD26,355,296 for each province of China. The lengths of the transportation routes (roads and highways) within the provinces were on average $79,358.71 \mathrm{~km}$ for each province over the given timeframe. 
Table 1: Summary and Descriptive Statistics

\begin{tabular}{|l|c|c|c|c|c|}
\hline Variables & Obs & Mean & Std. Dev. & Min. & Max. \\
\hline Exports & 620 & 15.389 & 1.879 & 9.069 & 20.271 \\
\hline Road length & 620 & 1.721 & .919 & -.994 & 3.407 \\
\hline GDP per capita & 620 & 9.411 & .904 & 7.331 & 11.509 \\
\hline Population & 620 & 8.061 & .901 & 5.455 & 9.344 \\
\hline Employment & 620 & 10.614 & .885 & 7.695 & 12.849 \\
\hline Investment & 620 & 7.429 & 1.411 & 3.053 & 10.513 \\
\hline WTO membership & 620 & .65 & .477 & 0 & 0 \\
\hline Financial crisis & 620 & .3 & .459 & \multicolumn{2}{|c|}{0} \\
\hline Location & 620 & .247 & .431 & & 1 \\
\hline
\end{tabular}

Table 2: Matrix of correlations

\begin{tabular}{|l|c|c|c|c|c|c|c|c|c|}
\hline Variables & exports & Ir & cgdp & pop & emp & inv & wto & fcr & loca \\
\hline exports & 1.000 & & & & & & & & \\
\hline Ir & 0.310 & 1.000 & & & & & & \\
\hline cgdp & 0.751 & 0.224 & 1.000 & & & & & \\
\hline pop & 0.506 & 0.609 & 0.007 & 1.000 & & & & & \\
\hline emp & 0.563 & 0.512 & 0.185 & 0.834 & 1.000 & & & & \\
\hline inv & 0.839 & 0.613 & 0.811 & 0.551 & 0.610 & 1.000 & & \\
\hline wto & 0.404 & 0.425 & 0.655 & 0.043 & -0.002 & 0.597 & 1.000 & & \\
\hline fcr & 0.421 & 0.428 & 0.696 & 0.043 & 0.144 & 0.647 & 0.480 & 1.000 & \\
\hline loca & 0.462 & -0.102 & 0.242 & 0.109 & 0.092 & 0.201 & -0.019 & -0.007 & 1.000 \\
\hline
\end{tabular}

Annual per-capita gross domestic product averaged at 18,288.52 Yuan per person for each province with a minimum value of 1,527 and a maximum value of 99,607 Yuan per person between the given time period of 20 years. The regional population was high for the provinces with the minimum value of 2,340,000 persons and maximum of $114,300,000$ persons with an average of 42,910,000 persons. The employment in the transport sector was average at $55,860.32$ attaining the lowest level of 2,198 and the highest level of 380,485 for the given provinces of China.

The dummy variables assumed only two values of minimum 0 and maximum 1 for both entry into WTO and financial crisis. $65 \%$ of the observations were explained after China's entry into the WTO while $35 \%$ was explained by the Financial Crisis after 2008. Year dummies of 20 years ranging from1997-2016 have also been tabulated and presented in the Appendix.

\section{Results and Discussion}

The results were estimated through STATA, and several tests were undertaken in order to verify the validity of the Model. Nested OLS model and Hausman fixed and random effects were used in order to understand if there exists any relationship between the variables. Table 2 shows the correlations between the variables.

It is noted that all the correlation values are below the threshold level of 0.7 , which is the desirable outcome for the correlation. The estimates further suggests that most our variables are moderately correlated i.e., value between 0.3 and 0.7 .

\subsection{Interpretation and Discussion on Final Estimations}

Table 3 presents the fixed effect regression model of the variables and explains the estimations and results of the final model. The estimation in the table shows that our main variable, the length of the Road and Highways within the provinces, as expected has a strong positive and significant impact on the exports and trade flows of the provinces. The elasticity is 0.69 , which is high showing a significant effect. The results were estimated through a series of tests applied to the variables. The main independent variable lr i.e., length of the transport route shows expected positive sign when tested through fixed effect. The longer the length of the roads, the bigger will be the exports of the province. The results are in line with the assumptions of the Theory of Modeling Trade. 
Imran Ur RAHMAN, Buddhi Prasad SHARMA, Enitilina FETUU, Muhammad YOUSAF /

Table 3: Nested Fixed and Random Effects Regressions

\begin{tabular}{|c|c|c|c|c|c|c|c|}
\hline \multirow{2}{*}{ Variables } & Inexp & Inexp & Inexp & Inexp & Fixed Effects & Random Effects & Robust Fixed \\
\hline & (1) & (2) & (3) & (4) & (5) & (6) & (7) \\
\hline \multirow{2}{*}{$\| r$} & $1.796^{\star \star *}$ & $0.637^{* * *}$ & $0.67^{\star \star \star}$ & $0.698^{* * *}$ & $0.693^{\star \star *}$ & $0.294^{* * *}$ & $0.693^{* * *}$ \\
\hline & $(0.033)$ & $(0.07)$ & $(0.069)$ & $(0.071)$ & $(0.072)$ & $(0.065)$ & $(0.072)$ \\
\hline \multirow{2}{*}{ Icgdp } & & $0.852^{* * *}$ & $0.779^{* * *}$ & $0.755^{\star * *}$ & $0.743^{* * *}$ & $1.093^{* * *}$ & $0.729^{\star * *}$ \\
\hline & & $(0.048)$ & $(0.05)$ & $(0.051)$ & $(0.064)$ & $(0.061)$ & $(0.145)$ \\
\hline \multirow{2}{*}{ Ipop } & & & $0.909^{* * *}$ & $0.852^{* * *}$ & $0.819^{\star \star \star}$ & $0.79^{\star * *}$ & $0.83^{* * *}$ \\
\hline & & & $(0.206)$ & $(0.207)$ & $(0.213)$ & $(0.104)$ & $(0.238)$ \\
\hline \multirow{2}{*}{ lemp } & & & & $0.078^{* *}$ & $0.087^{* *}$ & 0.058 & $0.087^{* *}$ \\
\hline & & & & $(0.038)$ & $(0.04)$ & $(0.044)$ & $(0.041)$ \\
\hline \multirow{2}{*}{ wto } & & & & & 0.035 & -0.022 & 0.035 \\
\hline & & & & & $(0.054)$ & $(0.058)$ & $(0.055)$ \\
\hline \multirow{2}{*}{ fcr } & & & & & -0.002 & -0.099 & -0.004 \\
\hline & & & & & $(0.06)$ & $(0.065)$ & $(0.062)$ \\
\hline \multirow{2}{*}{ loca } & & & & & -0.036 & $0.148^{* *}$ & -0.037 \\
\hline & & & & & $(0.07)$ & $(0.074)$ & $(0.071)$ \\
\hline \multirow{2}{*}{$\operatorname{linv}$} & & & & & & & 0.01 \\
\hline & & & & & & & $(0.095)$ \\
\hline Year Dum. & Yes & Yes & Yes & Yes & Yes & Yes & Yes \\
\hline \multirow{2}{*}{ cons } & $12.298^{* * *}$ & $6.273^{* * *}$ & -0.421 & -0.612 & -0.33 & $-2.372^{* *}$ & -0.362 \\
\hline & $(0.06)$ & $(0.34)$ & $(1.555)$ & $(1.553)$ & $(1.687)$ & $(0.947)$ & $(1.714)$ \\
\hline Observations & 620 & 620 & 620 & 620 & 620 & 620 & 620 \\
\hline R-Squared & 0.096 & 0.508 & 0.545 & 0.535 & 0.529 & 0.758 & 0.895 \\
\hline HChi-Square & - & - & - & - & \multicolumn{2}{|c|}{$251.28^{\star * *}$} & - \\
\hline
\end{tabular}

Note: Standard errors are in parentheses and ${ }^{* * *} p<.01,{ }^{* *} p<.05,{ }^{*} p<.1$ indicate significance of $p$-value.

Similarly, the coefficients of $1 \mathrm{r}$, cgdp, and population are significant at $1 \%$ significant level showing a highlevel significance. The coefficient of employment is also significant, but at 5\% level of significance. Regional GDP, population and employment have positive and significant impact on the exports of the provinces. On the other hand, dummy variables in the model have shown diverse results as expected. The dummy for WTO is positive, while that of Financial Crisis is negative. The positive sign for WTO explains that the exports of each province increased after China's entry into WTO than before the membership. The negative sign for "fr" suggests that after financial crisis the exports of the provinces decreased as compared to the value of exports before the Crisis. Additionally, in case of fixed effect the impacts of both dummy variables are insignificant and this phenomenon can be explained in details in case of China.
Now, explaining the marginal effect of the model estimations, we can analyze that, ceteris paribus, $1 \%$ increase in the length of the transportation routes (roads and highways) within the provinces increases the provincial exports by $0.69 \%$, which shows a high and positive impact of roads and highways within the provinces on the exports of the region. This result is in accordance with our expectations and provides further proof of past studies. Similarly, per-capita GDP of the provinces also shows a positive relationship with the dependent variable with a coefficient of 0.74 , which explains that $1 \%$ increase in per-capita GDP raises the regional exports by $0.74 \%$. The coefficient of the population came up with the expected sign and can be explained in terms that a $1 \%$ growth in the population can lead to $0.82 \%$ rise in the value of exports. This can be explained in terms of easy availability of skilled and lowcost labor in the case of China. 
The employment in the transport sector has indirect impact on regional exports and is low as compared to other variables. The coefficient as of employment (emp) is also positive and determines that if the employment in the transport sector is increased by $1 \%$, then the provincial exports are estimated to rise by $0.08 \%$. Moreover, the dummy variables also are with expected signs, but with low level of significance. Results for the dummy variable "wto" show that after China's entry into WTO led to increase of the provincial exports by $0.03 \%$.

On the other hand, dummy variable for financial crisis as represented by the symbol "fr" proved to be negative with the provincial exports and described that after financial crisis the provincial exports were reduced by $0.002 \%$, which is really low. The impact of financial crisis was not severe on the regional exports and the reason is presumed to be the overall growth rate of China and the trade within the regions, which were in operation in similar conditions as before the crisis. The year-on-year dummies tabulated in the Appendix

Table 4 show that China's exports continued to increase after the financial crisis. The policies of China and support to the industries by the Government played a vital role in maintaining the growth in trade. The value of R-squared for the model using the current variable is given by 0.529 for fixed effects ( 0.758 for random effects), which shows that the independent variables have the potential to explain $52.9 \%$ of the dependent variable. Similarly, the standard errors for all the variables are also low.

Following the OLS model, the selection of an appropriate model was tested through the Hausman Test. The null hypothesis for the Hausman test is that the preferred model is random versus the alternative where the model is specified as fixed effects (Hausman, 2015). The null hypothesis assumes that random effect is appropriate for the model. As presented in Table 3, the value of $\mathrm{Chi}^{2}$ is 251.2 with probability of the Chi-square given by $0.00<0.05$, which concludes that the null hypothesis is rejected and our variables are best appropriate for the fixed effect regression model.

Finally, in order to check the robustness in our crude model, we added a new variable, i.e., regional investment in the transport sector (inv) in our crude model. The results of the estimations for robustness are presented in Table 3. The coefficients, standard errors and level of significance of all the crude variables of the regression model are almost the same as they were before the inclusion of the new variable. Thus, it can be concluded that the current fixed effect model is appropriate with robust estimates with the main variables.

\section{Conclusion and Policy Recommendations}

The main objective of the paper was to determine and assess the impact of local roads and highways on regional exports and trade under the Theory of Modeling Trade and
Gravity Model analysis. This paper shows further evidence of the fact that the more roads and highways within a region increase the exports and trade of that region. Furthermore, regional employment in the sector is also high and has a significant impact on regional trade and productions. Roads and highways are one of the key factors that affect countries in a positive way. As the exports demand is growing, need for more and improved roads and highways within the country is increasing. Roads and highways provide easy means of transport and thus reduce the burden on the seaports. Similarly, for the transportation of goods and services of other non-coastal regions to the ports of the east, roads, and highways are the most important means of transport.

Road transport is the second-best alternative for China to carry out its trade with other countries. For this reason, the government has taken serious steps to expedite the projects of construction of new roads and improvement of the present roads and highways. The Belt and Road Initiative (BRI) or One Belt One Road (OBOR), and CPEC projects are one of the key determinants in this regards. These projects will have huge implications in terms of changing the trade patterns in OBOR countries. Moreover, coverage of road and highways networks in the western regions will provide gateways to foster trade of China between South and Central Asian Countries. By doing so the trade will enhance and economic activities will increase. Smooth flow of traffic and transportation of goods and services in addition to accessibility to local and international markets will be the key outcomes of roads and highways for China and developing nations under the BRI projects.

\section{References}

Akpan, U. (2014). Impact of Regional Road Infrastructure Improvement on Intra-Regional Trade in ECOWAS. African Development Review, 26(S1), 64-76. https://doi. org/10.1111/1467-8268.12093

Anderson, J. E., \& Van Wincoop, E. (2003). Gravity with gravitas: A solution to the border puzzle. American Economic Review, 93(1), 170-192, https://doi.org/10.1257/000282803321455214

Anderson, J. E., \& Van Wincoop, E. (2004). Trade costs. Journal of Economic Literature, 42(3), 691-751. https://doi. org/10.1257/0022051042177649

Blyde, J. (2013). Paving the Road to Export: Assessing the Trade Impact of Road Quality. International Economic Journal, 27(4), 663-681. https://doi.org/10.1080/10168737.2012.7337 21

Buys, P., Deichmann, U., \& Wheeler, D. (2010). Road network upgrading and overland trade expansion in sub-saharan Africa. Journal of African Economies, 19(3), 399-432. https://doi. org/10.1093/jae/ejq006

Calderon, C., \& Serven, L. (2010). Infrastructure and Economic Development in Sub-Saharan Africa. Journal of African Economies, 19(1), 13-87. https://doi.org/10.1093/jae/ejp022 
Imran Ur RAHMAN, Buddhi Prasad SHARMA, Enitilina FETUU, Muhammad YOUSAF /

Casaburi, L., Glennerster, R., \& Suri, T. (2012). Rural Roads and Intermediated Trade: Regression Discontinuity Evidence from Sierra Leone. SSRN Electronic Journal. https://doi.org/10.2139/ ssrn. 2161643

Celbis, M. G., Nijkamp, P., \& Poot, J. (2014). Infrastructure and trade: A meta-analysis. Region, 1(1), 25-54. https://doi. org/10.18335/region.v1i1.25

Chandra, A., \& Thompson, E. (2000). Does public infrastructure affect economic activity? Evidence from the rural interstate highway system. Regional Science and Urban Economics, 30(4), 457-490. https://doi.org/10.1016/S0166-0462(00)00040-5

Coşar, A. K., \& Demir, B. (2016). Domestic road infrastructure and international trade: Evidence from Turkey. Journal of Development Economics, 118, 232-244. https://doi. org/10.1016/j.jdeveco.2015.10.001

Coulibaly, S., \& Fontagné, L. (2006). South-South trade: Geography matters. Journal of African Economies, 15(2), 313-341. https:// doi.org/10.1093/jae/eji030

Dorosh, P., Wang, H.-G., You, L., \& Schmidt, E. (2010). Crop Production and Road Connectivity in Sub-Saharan Africa A Spatial Analysis. World Bank Policy Research Working Paper Series No. 5385. Washington, DC: World Bank. http:// documents1.worldbank.org/curated/en/319731468006253963/ pdf/WPS58 35.pdf

Dorosh, P., Wang, H. G., You, L., \& Schmidt, E. (2012). Road connectivity, population, and crop production in Sub-Saharan Africa. Agricultural Economics, 43(1), 89-103. https://doi. org/10.1111/j.1574-0862.2011.00567.x

Duranton, G. (2015). Roads and trade in Colombia. Economics of Transportation, 4(1-2), 16-36. https://doi.org/10.1016/j. ecotra.2014.11.003

Duranton, G., Morrow, P. M., \& Turner, M. A. (2013). Roads and trade: Evidence from the US. Review of Economic Studies, 81(2), 681-724. https://doi.org/10.1093/restud/rdt039

Fan, S., \& Zhang, X. (2004). Infrastructure and regional economic development in rural China. China Economic Review, 15, 2003-214. https://doi.org/10.1016/j.chieco.2004.03.001

Francois, J., Universit, J. K., \& Manchin, M. (2007). Institutions, Infrastructure, and Trade. World Development, 46, 165-175. https://doi.org/10.1016/j.worlddev.2013.02.009

Hausman, J. A. (2015). Specification tests in econometrics. Applied Econometrics, 38(2), 112-134. https://doi.org/10.2307/ 1913827

Kim, B. S., \& Kim, B. Y. (2020). The effect of selection factors of marine transportation service on transaction continuity. Journal of Asian Finance, Economics and Business, 7(1), 217-228. https://doi.org/10.13106/jafeb.2020.vol7.no1.217

Li, Z., Yu, X., Zeng, Y., \& Holst, R. (2012). Estimating transport costs and trade barriers in China: Direct evidence from Chinese agricultural traders. China Economic Review, 23(4), 10031010. https://doi.org/10.1016/j.chieco.2012.05.001

Limao, N. (2001). Infrastructure, Geographical Disadvantage, Transport Costs, and Trade. The World Bank Economic Review, 15(3), 451-479. https://doi.org/10.1093/wber/15.3.451

Michaels, G. (2008). The effect of trade on the demand for skill: Evidence from the interstate highway system. Review of Economics and Statistics, 90(4), 683-701. https://doi. org/10.1162/rest.90.4.683

Molina, D. (2008). Bilateral transport cost, infrastructure, common bilateral ties and political stability. Revista de Economia Del Rosario, 11(2), 221-247. https://doi.org/10.12804/revistas. urosario.edu.co/economia/a.1130

Molina, D., Mesquita, M., Blyde, J., \& Volpe, C. (2013). The Role of Transport Costs in Mexico's Regional Disparities. In: Too Far To Export. Domestic Transport Costs and Regional Export Disparities in Latin America and the Caribbean.

NBS China. (2020). National Bureau of Statistics of China Webiste. http://www.stats.gov.cn/enGliSH/

Ndulu, B. J. (2006). Infrastructure, regional integration and growth in sub-saharan Africa: Dealing with the disadvantages of geography and sovereign fragmentation. Journal of African Economies, 15(2), 212-244. https://doi.org/10.1093/jae/ej1033

Potluri, R. M., \& Tejaswi, S. P. (2018). Challenges of transport sector in India: A dyadic perspective. Journal of Asian Finance, Economics and Business, 5(3), 95-102. https://doi. org/10.13106/jafeb.2018.vol5.no3.95

Services, T. (2002). B infrastructure in trade and economic development. Geographical, 114-148.

The World Bank. (2015). World Development Indicators. Washington, DC: The World Bank.

The World Bank. (2018). The Logistics Performance Index and Its Indicators. Washington, DC: The World Bank.

Venables, A. J., \& Limão, N. (2002). Geographical disadvantage: A Heckscher-Ohlin-von Thünen model of international specialisation. Journal of International Economics, 58(2), 239263. https://doi.org/10.1016/S0022-1996(01)00168-4

Yessekina, A., \& Urpekova, A. (2015). Energy Efficiency and CO2 Emissions of the Transportation System of Kazakhstan: A Case of Almaty. Journal of Asian Finance, Economics and Business, 2(3), 41-46. https://doi.org/10.13106/jafeb.2015.vol2.no3.41. 


\section{Appendix}

Table 4: Regression Results

\begin{tabular}{|c|c|c|c|c|c|c|c|}
\hline Inexp & Coef. & St.Err. & t-value & p-value & [95\% Conf & Interval] & Sig \\
\hline$\| r$ & .62 & .077 & 8.03 & 0 & .468 & .771 & $* * *$ \\
\hline lcgdp & .348 & .186 & 1.87 & .062 & -.018 & .714 & * \\
\hline Ipop & .388 & .235 & 1.65 & .099 & -.073 & .849 & * \\
\hline lemp & .253 & .053 & 4.77 & 0 & .357 & .149 & $* * *$ \\
\hline linv & .229 & .093 & 2.47 & .014 & .411 & .047 & ** \\
\hline wto & 1.117 & .258 & 4.33 & 0 & .61 & 1.624 & $* * *$ \\
\hline $\mathrm{fcr}$ & .988 & .157 & 6.31 & 0 & .68 & 1.296 & $* * *$ \\
\hline yr2 & .13 & .086 & 1.51 & .132 & -.039 & .299 & \\
\hline yr3 & .026 & .097 & 0.27 & .786 & -.164 & .216 & \\
\hline $\mathrm{yr} 4$ & .153 & .106 & 1.44 & .149 & -.055 & .361 & \\
\hline yr5 & -.02 & .111 & -0.18 & .856 & -.238 & .198 & \\
\hline yr6 & -.053 & .117 & -0.45 & .651 & -.283 & .177 & \\
\hline $\mathrm{yr} 7$ & .163 & .128 & 1.27 & .206 & -.09 & .415 & \\
\hline yr8 & -1.072 & .157 & -6.82 & 0 & -1.381 & -.763 & $* * *$ \\
\hline yr9 & -.945 & .147 & -6.45 & 0 & -1.232 & -.657 & $* * *$ \\
\hline yr10 & -.529 & .125 & -4.24 & 0 & -.774 & -.284 & $* * *$ \\
\hline $\mathrm{yr} 11$ & -.301 & .108 & -2.79 & .005 & -.514 & -.089 & $* * *$ \\
\hline $\mathrm{yr} 12$ & -.132 & .096 & -1.36 & .173 & -.321 & .058 & \\
\hline $\mathrm{yr} 13$ & -.205 & .082 & -2.51 & .012 & -.366 & -.045 & ** \\
\hline o.yr14 & 0 & . & . & . & . & . & \\
\hline $\mathrm{yr} 15$ & -.773 & .136 & -5.68 & 0 & -1.04 & -.505 & $* * *$ \\
\hline yr16 & -1.058 & .123 & -8.59 & 0 & -1.3 & -.816 & $* * *$ \\
\hline $\mathrm{yr} 17$ & -.713 & .107 & -6.66 & 0 & -.923 & -.503 & $* * *$ \\
\hline yr18 & -.482 & .096 & -5.03 & 0 & -.67 & -.294 & $* * *$ \\
\hline yr19 & -.2 & .081 & -2.48 & .013 & -.359 & -.042 & ** \\
\hline o.yr20 & 0 & . & . & . & . & . & \\
\hline Constant & 11.584 & 2.441 & 4.74 & 0 & 6.789 & 16.379 & $* * *$ \\
\hline R-squared & 269.790 & & & & & & \\
\hline
\end{tabular}

Note: Significance level of $p$-value as ${ }^{* * *} p<.01,{ }^{* *} p<.05,{ }^{*} p<.1$. 